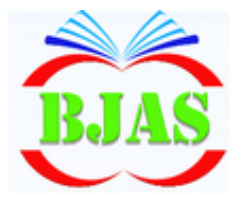

ISSN $1814-5868$
Available online at http://bjas.bajas.edu.iq

https://doi.org/10.37077/25200860.2022.35.1.02

College of Agriculture, University of Basrah

\section{Basrah Journal of Agricultural Sciences}

E-ISSN: 2520-0860

\title{
Growth Performance of Black poplar (Populus nigra L.) Under Drought Condition and Sewage Water Irrigation
}

\author{
Sirwa A. Qadir' ${ }^{1}$ \& Halmat A. Sabr ${ }^{2 *}$ \& Abdulqader M. Younis ${ }^{3}$ \\ ${ }^{1}$ Department of Forestry, College of Agricultural Engineering Sciences, Salahaddin University, \\ Erbil, Iraq \\ ${ }^{2}$ Department of Forestry, College of Agricultural Engineering Sciences, Salahaddin University, \\ Erbil, Iraq \\ ${ }^{3}$ Department of Health and Environmental Science, College of Sciences, Salahaddin University, \\ Erbil, Iraq
}

*Corresponding author email: halmat.sabr@su.edu.krd; halmat.forest86@gmail.com

Received $8^{\text {th }}$ March 2021; Accepted 22 July 2021; Available online 23 February 2022

\begin{abstract}
The response of black poplar (Populus nigra L.) seedlings to the combination of both drought and sewage water irrigation have been investigated from 18-5-2019 to 18-82019. Two drought stress levels; D0; $90 \%$ or full water holding capacity (WHC) and D1; $30 \%$ WHC interacted with three sewage irrigation treatments; S0; $100 \%$ of tap water as a control, S1; $50 \%$ of tap water and sewage water and S2; $100 \%$ of sewage water. The irrigation water quality index (IWQI) of S1 was 59.31 located under moderate restrictions class for irrigation purposes. Despite to its low pollution load index (PLI); 0.47. Fully irrigation to soil holding capacity with S1 (S1D0) led to a significant increase in seedling height, stem base diameter, fresh and dry biomass and moisture content in shoot system. In addition, the highest tolerance index (TI \%) about $92.07 \%$ of the seedlings recorded despite to the soil toxicity with $\mathrm{Ni}$ and $\mathrm{Pb}$ ions. Lowest accumulation and metal toxicity of $\mathrm{Cu}, \mathrm{Zn}$, $\mathrm{Cd}, \mathrm{Pb}$ and $\mathrm{Mn}$ in the soil and leaves have been determined. Thus, diluting sewage water; 1:1 can be used to irrigate black poplar trees with high water demand and moderate to high tolerance to salts for reforestation and urban vegetation.
\end{abstract}

Keywords: Heavy metals, Seedling biomass, Sewage water, Metal accumulation, Populus nigra.

\section{Introduction}

It is common in arid regions of the world are generally noted for their low primary productivity which is because of a combination of low, unpredictable water supply and low soil nutrient concentrations (Peek \& Forseth, 2003). Plant adaptation to dry conditions has been studied with high degree of water limitation tolerance, larger biomass allocation to roots, and greatly capable utilization of water (Patterson et al., 1997). Applying of recycled wastewater in tree irrigation may assist in decreasing the problem of the limited availability of freshwater this have been proved by many authors (Bedbabis et al., 2009). Hasan et al. (2009) stated that when metals are added in soil, turn out to be toxic as can interrupt 
physiology characterizes of plants and as a result plant development can be affected. Furthermore, the pigment synthesis concentrations can be reduced in the occurrence of metals, leading to decreasing photosynthetic efficiency (Maleva et al., 2012). Trees in forests are commonly less exposed to metal deposition as a result lack of human activities, such as intensive agriculture, industry, waste disposal and traffic vehicles, than trees in urban areas (Hermle et al., 2006).

Black poplar (Populus nigra L.) is a deciduous species that require high water capacity soil. The species is broadly distributed across Europe, Asia and northern Africa. It is a large fast-growing tree, with height of more than $40 \mathrm{~m}$ and stem diameters of up to $200 \mathrm{~cm}$ in native areas (de Rigo et al., 2016). In Kurdistan region species is consider as an important species for producing coppicing especially for demanding local markets. It is a windpollinated tree species. P. nigra $\mathrm{L}$. can be propagated both in vegetative ways (by cuttings) and generative (by wind- and waterdispersed seeds) (Prada et al., 2009).

Decreased water availability related with low flows may affect the water relations of require riparian tree species and reduce growth and survival (Lambs et al., 2006). Prolonged periods of poor growth and low survival will predictably lead to altered population structures and potential succession shifts in community composition (Smith et al., 1991). Lambs et al. (2006) stated that when poplar trees are exposed to low water availability to delay dehydration, require to close their stomata, shed leaves and increase root growth, however more severe water limitation leads to cease of photosynthesis process (Kramer, 1983). Furthermore, Poplar tree leaves typically showed very large stomata conductance that lead to high transpiration rates and the character of poplar canopies moderate the amount of water actually lost through transpiration even they are poorly together to the atmosphere such as intense solar radiation and warm temperatures (Hinckley et al., 1994; Dickman et al., 2001). However, the species adequate high-water supply, especially during the summer season. Therefore, its planting conditioned with sufficient water supply for forestation. In some cases, the use of sewage water in urban during the active growth period, represents an alternative source not only of water but also of nutrients. However, the presence of heavy metals in sewage water; $\mathrm{Cd}, \mathrm{Ni}$ and $\mathrm{Pb}$ could affect the viability of the plant. It is therefore important to evaluate the beneficial effects of sewage water to investigate growth performance of $P$. nigra L. under drought condition during summer season.

\section{Materials \& Methods}

\section{Treatments and experiment design}

The study was conducted in the lath house in Grdarasha field of the college of Agricultural Engineering Sciences, Salahaddin UniversityErbil. The seedlings of black poplar (P. nigra L.) were 4 months old and approximately their height ranged $30-40 \mathrm{~cm}$. Seedlings were subjected to water limitation and sewage effluent irrigation with different treatments for 90 days. The study was conducted as a Factorial experiment in a Complete Randomized design (CRD). Bearing two drought stress levels; D0; $90 \%$ or full water holding capacity (WHC) and D1; 30\% WHC interacted with three sewage irrigation treatments; S0; $100 \%$ of tap water as a control, S1; $50 \%$ of tap water and sewage water and S2; $100 \%$ of sewage water. Sewage water was taken from Erbil sewage channel 
near Turaq village in Erbil city. The field capacity was determined by saturating the soil in the pot, covering the tops with aluminum foil and weighing daily until there was no weight loss within 24, 48 and 72 hours' period. On this base $500 \mathrm{~mL}$ and $150 \mathrm{~mL}$ water added respectively as $(90 \%$ and $30 \%$ FC) field capacity (Qadir et al., 2019). Studied parameters

\section{Studied parameters of Turaq effluent:}

Electrical conductivity EC (APHA, 1989)

\section{Sodium adsorption ratio (SAR)}

The most common water quality factor that affect the normal rate of water infiltration is the relative proportions of sodium $\left(\mathrm{Na}^{+1}\right)$ to calcium $\left(\mathrm{Ca}^{+2}\right)$ and magnesium $\left(\mathrm{Mg}^{+2}\right)$ according to sodium adsorption ratio (SAR) equation. It was calculated based on standard equation followed by Ayers \& Westcott (1999).

$$
\boldsymbol{S A R}=\frac{\boldsymbol{N a}}{\sqrt[2]{\frac{C a+M g}{2}}}--- \text { Ayers \& Westcot (1999) }
$$

Where:

SAR: Sodium Adsorption Ratio (meg. $\left.1^{-1}\right)^{1 / 2}$

$\mathrm{Na}, \mathrm{Ca}$, and $\mathrm{Mg}$ : Concentration of $\mathrm{Na}^{+}, \mathrm{Ca}^{+2}$, and $\mathrm{Mg}^{+2}$ ions by milliequivalents per litre (meg. $1^{-1}$ ) units.

\section{Irrigation Water Quality Index (IWQI)}

The WQI was calculated to decide the level of pollution. In the first step, identified the parameters were considered more relevant to the irrigation use. In the second step, a definition of quality measurement values (qi) and aggregation weights (wi) was found. Values of (qi) were estimated based on each parameter value, according to irrigation water quality parameters proposed by the University Of California Committee Of Consultants-
UCCC and by the criteria established by Meireles et al. (2010).

$$
\begin{gathered}
Q_{i}=q_{i} \max -\left[\left(X_{i j}-X_{i n f} * q_{i a m p} / X_{a m p}\right]\right. \\
I W Q I=\Sigma q i w i
\end{gathered}
$$

Where qimax is the maximum value of qi for the class; $x_{i j}$ is the observed value for the parameter; $\mathrm{x}_{\text {inf }}$ is the corresponding value to the lower limit of the class to which the parameter belongs; qi $i_{a m p}$ is class amplitude; $\mathrm{X}_{\mathrm{amp}}$ is class amplitude to which the parameter belongs. In order to evaluate $\mathrm{x}_{\mathrm{amp}}$, of the last class of each parameter, the upper limit was considered to be the highest value determined in the physical-chemical and chemical analysis of the water samples. Each parameter weight used in the IWQI was obtained by (Meireles et al., 2010) as shown in table (1). The wi values were normalized such that their sum equals one.

Table (1): Weights for an IWQI parameters (Meireles et al., 2010).

\begin{tabular}{cc} 
Parameters & WI \\
\hline $\mathrm{EC}$ & 0.211 \\
\hline $\mathrm{Na}+$ & 0.204 \\
\hline $\mathrm{HCO}_{3}$ & 0.202 \\
\hline $\mathrm{Cl}^{-}$ & 0.194 \\
\hline $\mathrm{SAR}$ & 0.189 \\
\hline Total & 1.000
\end{tabular}

IWQI is dimensionless parameter ranging from (0 to 100), qi is the quality of the $\mathrm{i}^{\text {th }}$ parameter, a number from (0 to 100), function of its concentration or measurement, wi is the normalize weight of the $\mathrm{i}^{\text {th }}$ parameter, function of its significance illustrates the overall changeability in water quality. The categories are divided based on the proposed water quality index, which is developed 
according to existent water quality indexes. The hazard of water salinity, slow infiltration of soil water, in addition to toxicity to plants are summarized in the classifications developed by Bernardo (1995) and Holanda \& Amorim, (1997).

\section{Pollution load Index (PLI)}

Pollution load index (PLI) is a criterion used to evaluate the heavy metals contamination in water. The PLI can be calculated by using the following equation (Ra et al., 2013):

$$
P L I=\sqrt[2]{C F 1 * C F 2 * C F 3 * \ldots \ldots \text { CFn }}
$$

where the $\mathrm{CF}$ is the contamination factor is defined as:

\section{$\mathbf{C . F}=\mathbf{C}_{\text {metal }} / \mathbf{C}_{\text {back ground }}$}

Where; $\mathrm{C}_{\text {metal }}$ is the concentration of metal $\mathrm{n}$, $\mathrm{C}_{\text {back ground }}$ is the concentration of the metal $\mathrm{n}$ in the control water sample and $\mathrm{n}$ is the total number of the studied metals. The CF values represent the degree to which the water is contaminated.

The CF values represent the degree to which the water is contaminated. $\mathrm{CF}<1$ indicates low contamination; $1 \leq \mathrm{CF} \leq 3$ indicates moderate contamination; $3 \leq \mathrm{CF} \leq 6$ means considerable high contamination, and $\mathrm{CF}>6$ refers to very high contamination (Abdullah et al., 2011).

\section{Studied growth parameters of $P$. nigra seedlings}

After nine weeks of the growing period the following parameters have been estimated:

\section{Seedling height $(\mathrm{cm})$}

The seedling heights $(\mathrm{cm})$ were measured at the base of seedling until terminal buds.

\section{Seedling base diameter}

All seedlings diameter at base $(\mathrm{mm})$ were measured by electronic caliper tool.

\section{Shoot fresh and dry biomass}

To calculate the fresh (FW) and dry (DW) weights of the biomasses, a digital balance was used. For DW determination, samples were oven-dried at $72{ }^{\circ} \mathrm{C}$ in the oven until a constant mass and weight of leaves and shoots $(\mathrm{g})$ were attained.

\section{Moisture content (MC \%)}

The moisture content of shoots was calculated depending on fresh weight (FW) and dry weight (DW) of seedlings (Zhou \& Qiu, 2005).

$$
M C \%=\frac{F W-D W}{F W} * 100
$$

Tolerance index: the tolerance index (TI) was calculated depending on biomass of stressed seedlings to control seedlings (Wiszniewska et al., 2017).

$$
\text { TI } \%=\frac{\text { Biomass of stressed plant }(\mathrm{g})}{\text { Biomass of control plant }(\mathrm{g})} * 100
$$

\section{Statistical analysis}

The experiment set in a factorial with a Complete Randomized Design (CRD) with three sewage irrigation treatments; $\mathrm{S} 0, \mathrm{~S} 1$ and S2 and two drought stress levels; D0 90\% and D1 $20 \%$ (WHC) with six treatment combinations were obtained S0D0, S0D1, S1D0, S1D1, S2D0, S2D1 each replicated three instances. Analysis of variance (ANOVA) of the data computed using the Statistical package for the Social Sciences (SPSS) model 25. The Duncan's test used to check the variations among the mean values of studied parameters. $5 \%$ level of possibility for lath house measurements and $1 \%$ degree for the laboratory measurements. 


\section{Results \& Discussion}

\section{Studied parameters of Turaq effluent}

The inability of the plant to compete with ions in the soil solution for water leads to physiological drought even though the soil may appear wet. The primary factor of physiological drought is the high electric conductivity (EC) of the soil solution. The higher the EC, the less water is available to plants. Because plants able to transpire "pure" water, only in the soil solution (Bauder et al., 2011). The electrical conductivity (EC) value of the S2 and S2 irrigation water were; 0.94 and $0.71 \mathrm{dS} . \mathrm{m}^{-1}$ (Table 2). The SAR value for S2 (100\% sewage water) and S1 (50\% sewage water) were 0.65 and 0.47 . At a given SAR the infiltration rate increases as salinity increases or the other way around. $\mathrm{Na}+\mathrm{Cl}-$, $\mathrm{HCO} 3, \mathrm{EC}$ and SAR were used to develop the proposed IWQI depending on (Ayers \& Westcot 1999). The IWQI of S1 was 59.31 located under moderate restrictions class for irrigation purposes, allowing it to be used to irrigate plants with moderate salt tolerance. The IWQI of S2 was 51.12 located under the high restriction class (Table 3) according to Bernardo (1995), Holanda \& Amorim (1997) and Meireles et al. (2010), S1 type of irrigation treatment can be used for irrigation of plants with moderate to high tolerance to salts with special salinity control practices, except water with low $\mathrm{Na}, \mathrm{Cl}$ and $\mathrm{HCO}_{3}$ values (Bernardo, 1995; Holanda \& Amorim, 1997).

Table (2): Chemical analysis of irrigation treatments.

\begin{tabular}{|c|c|c|c|}
\hline \multirow{2}{*}{ Parameters } & \multicolumn{3}{|c|}{$\begin{array}{c}\text { Sewage Irrigation } \\
\text { treatments }(S)\end{array}$} \\
\hline & $\begin{array}{c}\text { Control } \\
\text { (S0) }\end{array}$ & $\begin{array}{r}50 \% \\
(\mathrm{~S} 1)\end{array}$ & $\begin{array}{c}100 \% \\
(\mathrm{~S} 2)\end{array}$ \\
\hline $\mathrm{EC}\left(\mathbf{d S} . \mathrm{m}^{-1}\right)$ & 0.54 & 0.71 & 0.94 \\
\hline Ca $\left(\right.$ meq..$\left.^{-1}\right)$ & 2.55 & 3.1 & 3.8 \\
\hline $\operatorname{Mg}\left(\right.$ meq..$\left.^{-1}\right)$ & 1.2 & 1.28 & 1.55 \\
\hline Cl (meq.. $\left.{ }^{-1}\right)$ & 0.37 & 0.8 & 1.08 \\
\hline $\mathrm{Na}\left(\right.$ meq. $\left.^{-1}\right)$ & 0.27 & 0.81 & 1.17 \\
\hline K meq..$\left.^{-1}\right)$ & 0.03 & 0.06 & 0.11 \\
\hline $\operatorname{SAR}\left(\right.$ meq. $\left.^{-1}\right)$ & 0.14 & 0.47 & 0.65 \\
\hline $\mathrm{HCO}_{3}\left(\right.$ meq. $\left.^{\mathrm{l}^{-1}}\right)$ & 3.44 & 4.42 & 5.4 \\
\hline
\end{tabular}

Table (3): Irrigation treatment Quality Index Classes.

\begin{tabular}{ccc} 
Irrigation treatments & IWQI & Water Use Restriction classes \\
\hline $\mathbf{1 0 0 \%}$ sewage water $(\mathbf{S 2})$ & 51.12 & High restriction \\
\hline $\mathbf{5 0 \%}$ sewage water $(\mathbf{S 1})$ & 59.31 & Moderate restriction
\end{tabular}

Except for nickel, the concentration and contamination factor levels for $\mathrm{Fe}, \mathrm{Cu}, \mathrm{Zn}$, $\mathrm{Cd}, \mathrm{Pb}$, and $\mathrm{Mn}$ in the treated soils with sewage irrigation and drought suggest a low degree of pollution (Tables $4 \& 5$ ). Previously described by Abdullah et al. (2011); the CF < 1 indicates low contamination. $\mathrm{Ni}$ level recorded higher than the background level in all treatment's combinations. The highest level of accumulation of $\mathrm{Ni} ; 281.16 \mathrm{ppm}$ was 
Qadir et al., / Basrah J. Agric. Sci., 35(1): 21-34, 2022

recorded at S2D0; when the P. nigra L. seedlings irrigated with complete sewage irrigation (S2) but $100 \%$ WHC \% drought stress level (D0) (Table 4). Because heavy metals that are present in wastewater used for irrigation tend to accumulate in the soils where there is a potential that they could become bioavailable for the plant (Toze, 2006). Pollution severity and its variation along the treatment combinations were determined with the use of pollution load index (PLI) (Tomlinson et al., 1980). PLI is presented in (Table 4).

Table (4): Combined effect of sewage irrigation and drought stress levels on metals concentrations in the soil.

Metals concentrations (ppm)

\begin{tabular}{cccccccc} 
Treatment & Fe & Ni & Cu & Zn & Cd & Pb & Mn \\
\hline S0D0 & 34813.49 & 262.74 & 30.98 & 70.95 & 2.85 & 7.65 & 761.60 \\
\hline S0D1 & 35730. & 246.71 & 28.11 & 51.77 & 1.14 & 7.34 & 711.28 \\
\hline S1D0 & 38756.61 & 252.87 & 31.19 & 63.26 & 0.95 & 12.36 & 777.04 \\
\hline S1D1 & 36026.76 & 270.75 & 26.51 & 58.09 & 2.19 & 8.35 & 769.09 \\
\hline S2D0 & 37336.22 & 281.16 & 32.95 & 65.35 & 1.37 & 12.95 & 764.43 \\
\hline S2D1 & 39086.01 & 279.65 & 22.17 & 54.77 & 1.78 & 9.01 & 763.60 \\
\hline Background & 50000 & 50 & 100 & 300 & 3 & 100 & 2000
\end{tabular}

Table (5): Combined effect of sewage irrigation and drought stress levels on contamination factor (CF) and pollution load index (PLI) in the soil.

\begin{tabular}{|c|c|c|c|c|c|c|c|c|}
\hline \multirow[t]{2}{*}{ Treatment } & \multicolumn{7}{|c|}{$\mathbf{C F}$} & \multirow[t]{2}{*}{ PLI } \\
\hline & $\mathbf{F e}$ & $\mathbf{N i}$ & $\mathbf{C u}$ & $\mathbf{Z n}$ & Cd & $\mathbf{p b}$ & Mn & \\
\hline SOD0 & 0.69 & 5.25 & 0.31 & 0.24 & 0.95 & 0.13 & 0.38 & 0.43 \\
\hline S0D1 & 0.72 & 4.93 & 0.28 & 0.17 & 0.38 & 0.09 & 0.36 & 0.43 \\
\hline S1D0 & 0.77 & 5.62 & 0.31 & 0.21 & 0.72 & 0.12 & 0.39 & 0.47 \\
\hline S1D1 & 0.75 & 5.42 & 0.27 & 0.19 & 0.33 & 0.08 & 0.38 & 0.44 \\
\hline S2D0 & 0.74 & 5.56 & 0.33 & 0.22 & 0.59 & 0.12 & 0.38 & 0.47 \\
\hline S1D1 & 0.78 & 5.09 & 0.22 & 0.18 & 0.46 & 0.09 & 0.38 & 0.58 \\
\hline
\end{tabular}


The results of pollution load index were found to be low $(\mathrm{PLI}<1)$ in all the treatment combinations. This indicates the low load of heavy metals in the studied soil samples. The PLI values for all samples are less than one indicating the role of external discrete sources, vehicle exhaust, and agricultural activities of soil pollution (Elnazer et al., 2015; Salman et al., 2019).

\section{Studied parameters of $\boldsymbol{P}$. nigra seedlings}

New attempts are currently being done to enhance the use of sewage water which is a scarce resource in many places around the world this can support nutrients and regarded as an effective alternative for the irrigation of certain plants (Faizan et al., 2014). However, sewage water may be regarded as a source of toxic trace elements such as cadmium, arsenic, and lead which are expected to be an environmental pollutant and toxic for animals and plants depending on its origin and quality. After 90 days of irrigation with sewage water irrigation treatments and drought stress levels a significant increase observed in the seedling height and stem base diameter (Fig. 1). The maximum height; $53.09 \mathrm{~cm}$ and widest base diameter of the shoot; $10.80 \mathrm{~mm}$ were recorded when the seedlings were fully irrigated with $50 \%$ sewage water and 100 WHC \% (S1D0) may be because of adequate ease of use of water and essential elements (Guo et al., 2006). A Result was found by Rigueiro-Rodriguez et al. (2000) that an increase in the height and diameter of pine stem, which were planted in plots irrigated with sewage water were significantly higher than trees growing in control plots. In addition a research as documented by Ostos et al. (2008) on woody cutting Pistacia lentiscus L. found the same results.
After 90 days a similar response in fresh and dry biomass as well as moisture content of the seedlings of black poplar species were observed with fully irrigation to soil holding capacity with $50 \%$ of sewage water (S1D0); $22.47,8.01 \mathrm{~g}$ and $64,35 \%$, respectively (Fig. 2). The finding of the study was in accordance with a study conducted by Ali $\mathrm{el}$ al. (2011); the sewage water had a positive impact on tree growth; with providing of the soil with plant nutrients and organic matter this can cause enhancing the soil physical characteristics that give consideration to the growth by improving the cell elongation and division. Furthermore, a study performed by Othman et al. (2016) on Pinus brutia Ten. Furthermore, Sabr \& Younis (2017) showed that the tap water treatment did not superior to $50 \%$ of tap water + sewage water and $100 \%$ of sewage water in improving the growth parameters and biomass except stem dry weight of Eucalyptus camadulensis Dehnh. seedlings and stem fresh weight and stem dry weight of Melia azaderach L. seedlings. Sewage effluent had an encourage effect on vegetative growth of trees due to its role in providing the soil with plant nutrients and organic matter and upgrade the physical characteristics of the soil, that affect the growth by enhancing the cell division and elongation. The results are explained by many other investigators; Abbaas (2002) on Casuarina glauca, Taxodium distichum and P. nigra, El-Sayed (2005) on Ceratonia siliqua, Acacia saligna and A. stenophylla.

Singh \& Bhati (2005) on Dalbergia sissoo and Ali et al. (2010) on Tipuana speciosa. Seedlings of Kurrajong tree Brachychiton populneus treated under the control showed higher dry weight of shoots respectively as compared to drought at both $60 \%$ and $30 \%$ (SWHC) (Karim et al., 2020). 


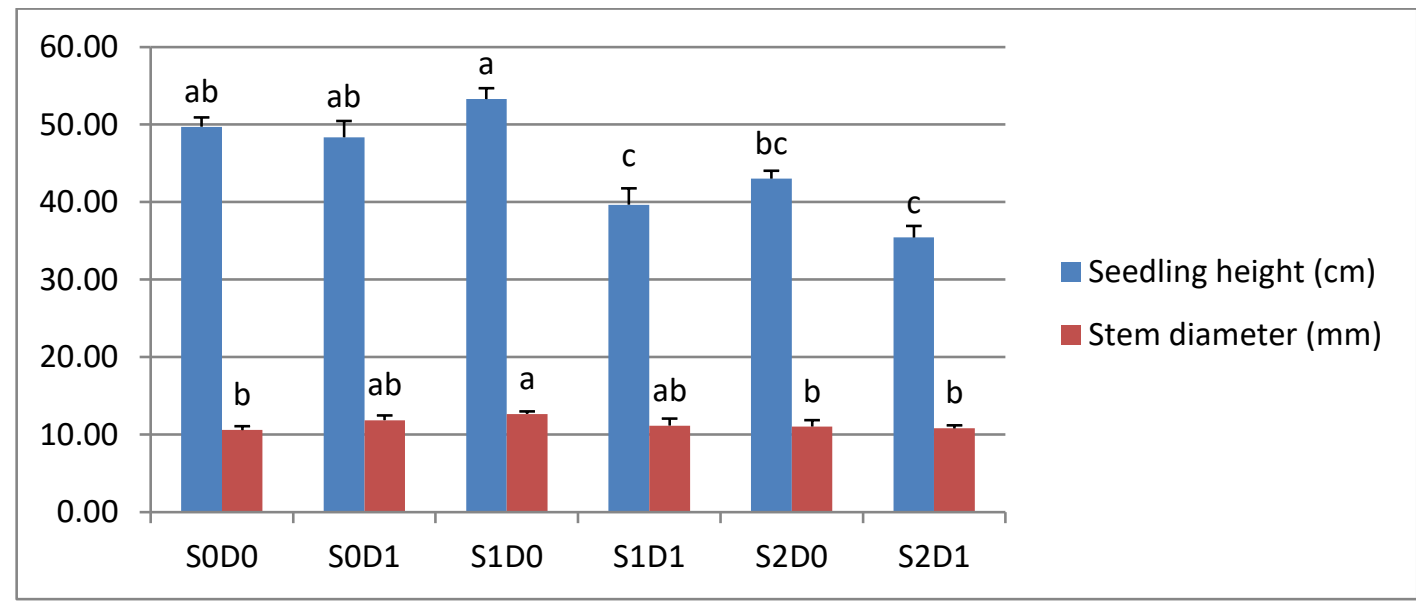

Fig. (1): Combined effect of sewage irrigation and drought stress levels on seedling height (cm) and stem diameter ( $\mathrm{mm})$ of $P$. nigra $\mathrm{L}$. seedlings.

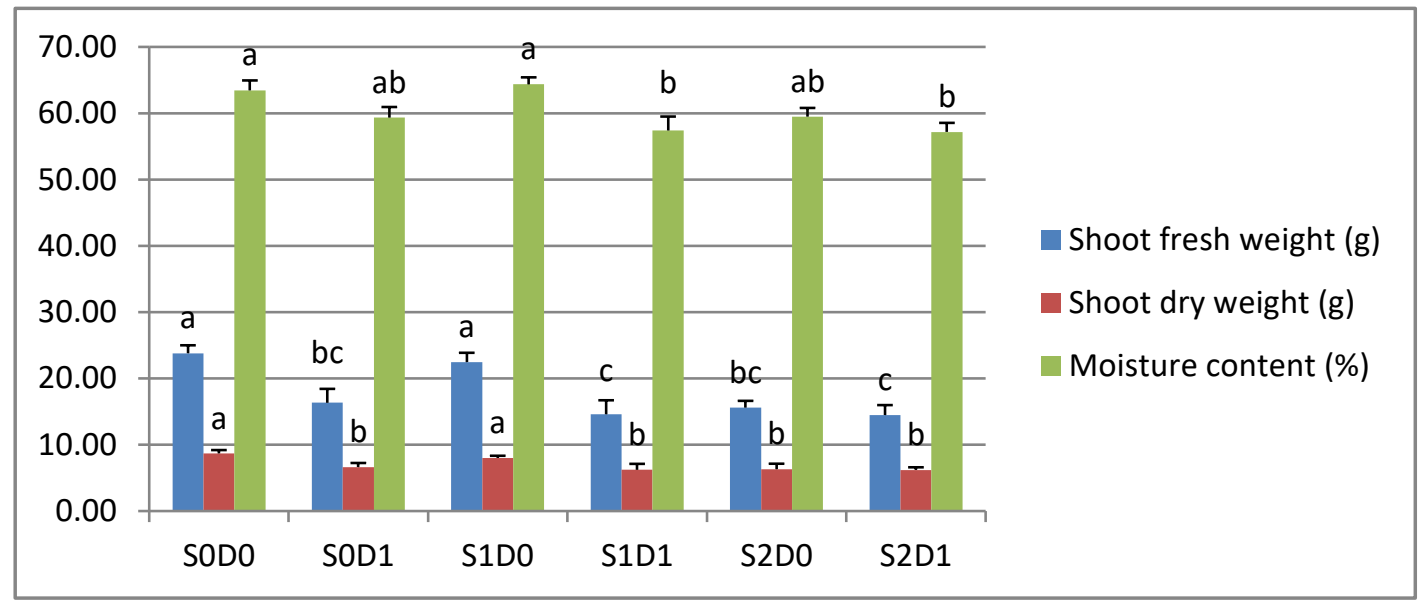

Fig. (2): Combined effect of sewage irrigation and drought stress levels on shoot fresh weight, shoot dry weight and shoot moisture content of $\boldsymbol{P}$. nigra L. seedlings.

Fig. (3) shows the tolerance index of $P$. nigra $\mathrm{L}$. that were irrigated for 90 days with different irrigation treatments. It was obvious that seedlings under complete water holding capacity with $50 \%$ of tap water and Touraq effluent shows best tolerance index $(92.07 \%)$ and showed no significant difference as compared to control treatment. Metal stress effects caused leaves to fall, leading to a reduction in total biomass (Gupta et al., 2013). It is well documented in various poplar species such as Populus tremula (Vollenwe- ider et al., 2011), Populus x euramericana (Di Baccio et al., 2003), Salix and Populus (Justin et al., 2010) and two clones of 1-yearold poplar trees (P. nigra cv. I-488 and Populus alba cv. MA-104) by Houda et al. (2016). The lowest accumulation of $\mathrm{Cu}, \mathrm{Zn}, \mathrm{Cd}, \mathrm{Pb}$ and Mn was recorded 6.16, 50.45, 3.31, 32.29 $32.94 \mathrm{ppm}$ respectively due to S1D0 (Table 6). Cd level; 3.31 and 32.29 ppm located near the toxic accumulation level in black poplar leaves. 
Table (6): Combined effect of sewage irrigation and drought stress levels on heavy metal concentration in shoots of $P$. nigra L. seedlings.

\begin{tabular}{cccccccc} 
Treatments & Fe (ppm) & Ni $(\mathbf{p p m})$ & $\begin{array}{c}\text { Cu } \\
(\mathbf{p p m})\end{array}$ & $\begin{array}{c}\mathbf{Z n} \\
(\mathbf{p p m})\end{array}$ & $\begin{array}{c}\text { Cd } \\
(\mathbf{p p m})\end{array}$ & $\begin{array}{c}\text { Pb } \\
(\mathbf{p p m})\end{array}$ & $\begin{array}{c}\text { Mn } \\
(\mathbf{p p m})\end{array}$ \\
\hline S0D0 & 00.00 & 00.00 & $18.25 \pm 1.78 \mathrm{ab}$ & $71.59 \pm 5.32 \mathrm{~b}$ & $2.74 \pm 0.91 \mathrm{a}$ & $34.30 \pm 6.78 \mathrm{~b}$ & $35.24 \pm 4.76 \mathrm{c}$ \\
\hline S0D1 & 00.00 & 00.00 & $20.69 \pm 3.12 \mathrm{a}$ & $75.18 \pm 11.37 \mathrm{a}$ & $2.05 \pm 1.12 \mathrm{a}$ & $25.69 \pm 3.56 \mathrm{~b}$ & $66.31 \pm 9 / 12 \mathrm{~b}$ \\
\hline S1D0 & 00.00 & 00.00 & $6.16 \pm 1.10 \mathrm{c}$ & $50.45 \pm 5.36 \mathrm{c}$ & $3.31 \pm 1.87 \mathrm{~b}$ & $32.29 \pm 6.98 \mathrm{~b}$ & $32.94 \pm 5.78 \mathrm{~d}$ \\
\hline S1D1 & 00.00 & 00.00 & $0.00 \pm 0.00 \mathrm{~d}$ & $59.92 \pm 7.12 \mathrm{c}$ & $3.66 \pm 1.65 \mathrm{~b}$ & $40.31 \pm 9 / 22 \mathrm{ab}$ & $70.18 \pm 16.18 \mathrm{a}$ \\
\hline S2D0 & 00.00 & 00.00 & $22.41 \pm 3.17 \mathrm{a}$ & $71.76 \pm 5.76 \mathrm{~b}$ & $2.80 \pm 0.88 \mathrm{a}$ & $48.10 \pm 11.56 \mathrm{a}$ & $50.55 \pm 8.17 \mathrm{c}$ \\
\hline S2D2 & 00.00 & 00.00 & $16.58 \pm 2.89 \mathrm{~b}$ & $78.37 \pm 12.13 \mathrm{a}$ & $4.58 \pm 2.11 \mathrm{c}$ & $44.28 \pm 13.54 \mathrm{a}$ & $69.63 \pm 18.33 \mathrm{a}$
\end{tabular}


Qadir et al., / Basrah J. Agric. Sci., 35(1): 21-34, 2022

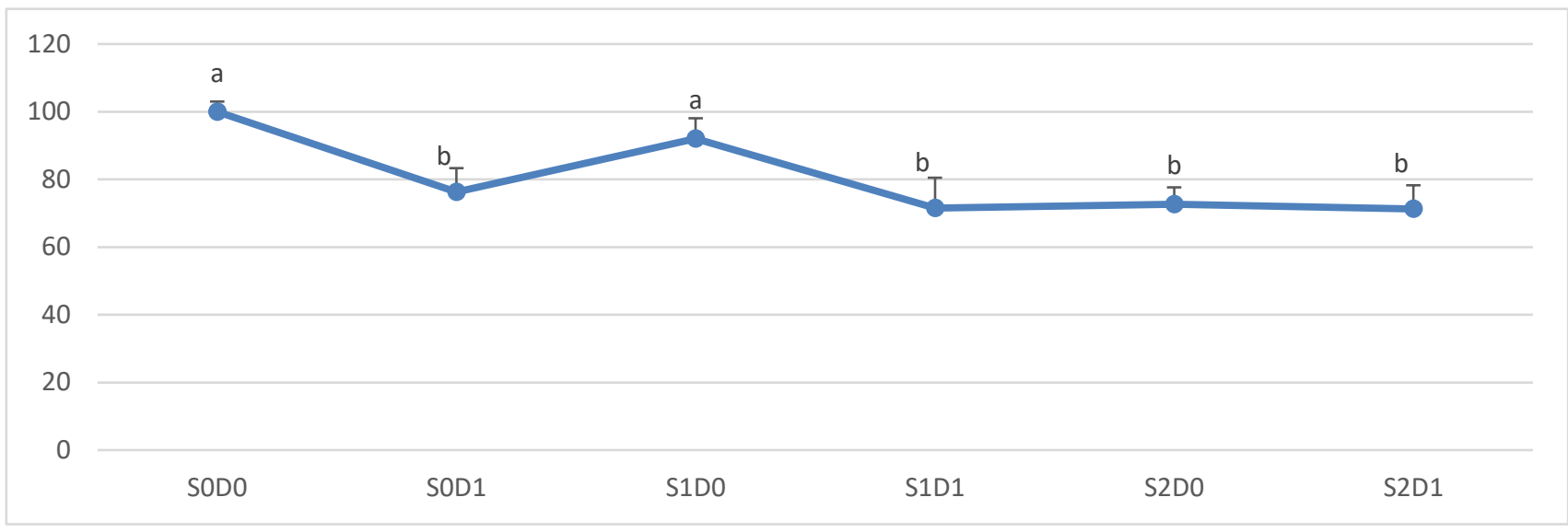

Fig. (3): Combined effect of sewage irrigation and drought stress levels on tolerance index (TI \%) of P. nigra L. seedlings.

However, it still was able to acclimatize as the $\mathrm{Cd}$ contamination level was greater than normal range without any reduce of morphological growth and biomass. Obviously, may be many genotypes of tree species can itself supply adequate biochemical diversity to make available low level of constituent metal tolerance (Turner \& Dickinson, 1993). Shi \& Cai (2009) documented that once $\mathrm{Cd}$ concentration in the plant tissue extends 3-10 mg. $\mathrm{kg}^{-1}$ that plants can experience toxic effects as many previous researches have recognized. Hajar el al. (2014) explained that heavy metals were in a normal range in plants except for $\mathrm{Cd}$ and $\mathrm{Pb}$. However, lead and cadmium concentrations in shoots were alleviated with the adding of sewage water supply in a soil.

\section{Conclusion}

Wastewater irrigation of urban fringe of large cities becomes a good practice, particularly in arid and semi-arid regions because of fresh water shortage. The irrigation solution composed of mixed with tap water 1:1 increased the growth and improved morphological and biomass production of black poplar seedlings. As well as being better acclimatize as the $\mathrm{Cd}$ contamination level in spite being greater than normal range without any reduce in morphological and biomass characters.

\section{Acknowledgements}

The authors greatly thank to Forestry department, college of Agricultural Engineering Sciences for providing a location to conduct a study.

\section{Conflict of interest}

The authors declared that they have no conflict of interest.

\section{References}

Abbaas, M. M., (2002). Effect of some heavy metals in the irrigation water on growth and chemical constituents of some timber trees. Ph. D. Thesis, Faculty of Agricultural. Faculty of Agricultural, Cairo University.

Abdullah, M. Z., Saat, A., \& Hamzah, Z. (2011). Optimization of energy dispersive $\mathrm{x}$-ray fluorescence spectrometerto analyze heavy metals in moss samples. Science Publications, 4, 355-362. 


\section{Qadir et al., / Basrah J. Agric. Sci., 35(1): 21-34, 2022}

Ali, H. M., El-Mahrouk, E. M., Hassan, F. A., \& Khamis, M. H., (2010). Growth, chemical compositions and soil properties of Tipuana speciosa irrigated with sewage effluent. In The 25th Meeting of Saudi Biological Society, Nanotechnology in Life Sciences, Alasa City at King Faisal University.

Ali, H. M., El-Mahrouk, E. S. M., Hassan, F. A., \& ElTarawy, M. A., (2011). Usage of sewage effluent in irrigation of some woody tree seedlings. Part 3: Swietenia mahagoni (L.) Jacq. Saudi Journal of Biological Sciences, 18, 201-207. https://doi.org/10.1016/j.sjbs.2010.08.001

American public Health Association (A.P.H.A). (1989). Standard methods for the examination of water and wastewater. 17th. Ed. A.P.H.A., 1015 Eighteenth Street NW. Washington, D.C., 2036pp.

Ayers, R. S., \& Westcot, D. W. (1999). The water quality in agriculture. 2nd. Campina Grande: UFPB. (Studies FAO Irrigation and drainage, 29).

Bauder, T. A., Waskom, R. M., Sutherland, P. L., \& Davis, J. G. (2011). Irrigation Water Quality Criteria. Colorado State University. Agriculture Publication No. 0.506 .

Bedbabis, S., Palese, A. M., Rouina, B. B., Rhouma, A. L. I., Gargouri, K., \& Boukhris, M., (2009). The effect of irrigation with treated wastewater on "chemlali" olive oil quality. Journal of Food Quality, 32, 141-157. https://doi.org/10.1111/j.17454557.2009.00242.x

Bernardo, S. (1995). Manual of Irrigation. $4^{\text {th }}$ edition, Vicosa: UFV, 488pp.

de Rigo, D., Enescu, C. M., Houston Durrant, T., \& Caudullo, G., (2016). Populus nigra in Europe: Distribution, habitat, usage and threats. European Atlas of Forest Tree Species.

Di Baccio, D., Tognetti, R., Sebastiani, L., \& Vitagliano, C., (2003). Responses of Populus deltoides $\times$ Populus nigra (Populus $\times$ euramericana) clone I-214 to high zinc concentrations. New Phytologist, 159, 443-452. https://doi.org/10.1046/j.14698137.2003.00818.x

Dickmann, D. I., Isebrands, J. G., Blake, T. J., Kosola, K., \& Kort, J., (2001). Chapter 3: Physiological ecology of poplars. Pp: 77-118. In Dickmann, D. I.,
Isebrands, J. G., Eckenwalder, J. E., \& Richardson, J. (Editors). Poplar Culture in North America, (Part A). NRC Research Press. Ottawa.

Elnazer, A. A., Salman, S. A., Seleem, E. M., \& Abu El Ella, E. M., (2015). Assessment of some heavy metals pollution and bioavailability in roadside soil of Alexandria-Marsa Matruh highway, Egypt. International Journal of Ecology, 2015, Article ID 689420. https://doi.org/10.1155/2015/689420

El-Sayed, N. A. A., (2005). The impact of irrigation with treated wastewater effluent on soil biophysicochemical properties and on growth and heavy metals content of some fodder trees grown on calcareous soil. Ph. D. Thesis, Faculty of Agricultural, Tanta University, Egypt

Faizan, S., Kausar, S. \& Akhtar, N., (2014). Influence of wastewater application and fertilizer use on growth, photosynthesis, nutrient homeostatis, yield \& heavy metal accumulation in okra (Abelmoschus esculentus L. Moench). Pakistan Journal of Biological Sciences, 17, .630-640.

Gupta, D. K., Huang, H. G., Nicoloso, F. T., Schetinger, M. R., Farias, J. G., Li, T. Q., Razafindrabe, B. H. N., Aryal, N., \& Inouhe, M., (2013). Effect of Hg, As and $\mathrm{Pb}$ on biomass production, photosynthetic rate, nutrients uptake and phytochelatin induction in Pfaffia glomerata. Ecotoxicology, 22, 1403-1412.

Guo, Z., Dirmeyer, P. A., Hu, Z. Z., Gao, X., \& Zhao, M., (2006). Evaluation of the second global soil wetness project soil moisture simulations: 2 . Sensitivity to external meteorological forcing. Journal of Geophysical Research: Atmospheres, 111(D22). https://doi.org/10.1029/2006JD007845

Hajar, E. W. I., Sulaiman, A. Z. B., \& Sakinah, A. M., (2014). Assessment of heavy metals tolerance in leaves, stems and flowers of Stevia rebaudiana plant. Procedia Environmental Sciences, 20, 386393.https://doi.org/10.1016/j.proenv.2014.03.049

Hasan, S. A., Fariduddin, Q., Ali, B., Hayat, S., \& Ahmad, A., (2009). Cadmium: toxicity and tolerance in plants. Journal of Environmental Biology, 30, 165-174.

Hermle, S., Günthardt-Goerg, M. S., \& Schulin, R., (2006). Effects of metal-contaminated soil on the performance of young trees growing in model 


\section{Qadir et al., / Basrah J. Agric. Sci., 35(1): 21-34, 2022}

ecosystems under field conditions. Environmental Pollution, 144, 703-714. https://doi.org/10.1016/j.envpol.2005.12.040

Hinckley, T. M., Brooks, J. R., Čermák, J., Ceulemans, R., Kučera, J., Meinzer, F. C., \& Roberts, D. A., (1994). Water flux in a hybrid poplar stand. Tree Physiology, 14, 1005-1018. https://doi.org/10.1093/treephys/14.7-8-9.1005

Holanda, J. S., \& Amorim, J. A. (1997). Management and control salinity and irrigated agriculture water" In: Brazilian Congress of Engineering setting, 26, Campina Grande, 137-169.

Houda, Z., Bejaoui, Z., Albouchi, A., Gupta, D. K., \& Corpas, F. J., (2016). Comparative study of plant growth of two poplar tree species irrigated with treated wastewater, with particular reference to accumulation of heavy metals $(\mathrm{Cd}, \mathrm{Pb}, \mathrm{As}$, and $\mathrm{Ni})$. Environmental Monitoring and Assessment, 188, 110. https://doi.org/10.1007/s10661-016-5102-0

Justin, M. Z., Pajk, N., Zupanc, V., \& Zupančič, M., (2010). Phytoremediation of landfill leachate and compost wastewater by irrigation of Populus and Salix: biomass and growth response. Waste Management, $\quad 30, \quad 1032-1042$. https://doi.org/10.1016/j.wasman.2010.02.013

Karim, S. A., Qadir, S. A., \& Sabr, H. A. (2020). Study some of morphological and physiological traits of Kurrajong Brachychiton populneus (Schott \&amp; Endl.) seedlings planted under water stress conditions. Basrah Journal of Agricultural Sciences, 33 , 213-220. https://doi.org/10.37077/25200860.2020.33.1.16.

Kramer P. J., (1983). Water used in plants. Academic Press, San Diego, C.A., 489pp.

Lambs, L., Loubiat, M., Girel, J., Tissier, J., Peltier, J. P., \& Marigo, G., (2006). Survival and acclimation of Populus nigra to drier conditions after damming of an alpine river, southeast France. Annals of Forest Science, 63, 377-385. https://doi.org/10.1051/forest:2006018

Maleva, M. G., Nekrasova, G. F., Borisova, G. G., Chukina, N. V., \& Ushakova, O. S., (2012). Effect of heavy metals on photosynthetic apparatus and antioxidant status of Elodea. Russian Journal of
Plant Physiology, 59, 190-197. https://doi.org/10.1134/S1021443712020069

Meireles, A., Andrade, E. M., Chaves L., Frischkorn, H., \& Crisostomo, L. A. (2010). A new proposal of the classification of irrigation water. Revista Ciência Agronômica, $\quad 41, \quad 349-357$. https://doi.org/10.1590/S1806-66902010000300005

Ostos, J. C., Lopez-Garrido, R., Murillo, J. M. \& Lopez, R. (2008). Substitution of peat for municipal solid waste-and sewage sludge-based composts in nursery growing media: Effects on growth and nutrition of the native shrub Pistacia lentiscus L. Journal of Bioresource Technology, 99, 1793-1800. https://doi.org/10.1016/j.biortech.2007.03.033.

Othman, B. A., Younis, A. M., \& Sabr, H. A., (2016). Effect of Sewage Water Irrigation on Growth Performance and Biomass for Pine Trees, Pinus brutia Ten. under Nursery Condition. Tikrit Journal for Agricultural Sciences, 16, 19-25.

Patterson, T. B., Guy, R. D., \& Dang, Q. L., (1997). Whole-plant nitrogen-and water-relations traits, and their associated trade-offs, in adjacent muskeg and upland boreal spruce species. Journal of Oecologia, 110, 160-168. https://doi.org/10.1007/s004420050145

Peek, M. S., \& Forseth, I. N., (2003). Microhabitat dependent responses to resource pulses in the arid land perennial, Cryptantha flava.Journal of Ecology, 91, 457-466. https://doi.org/10.1046/j.1365-2745.2003.00778.

Prada, A., \& González Martínez, S. C., (2009). Technical guide for genetic conservation and use of European black pine (Pinus nigra) in Spain. Forests in Spain.

Qadir, S. A., Khursheed, M. Q., Rashid, T. S., \& Awla, H. K., (2019). Abscisic acid accumulation and physiological indices in responses to drought stress in wheat genotypes. The Iraqi Journal of Agricultural Science, 50, 705-712.

Ra, K., Kim, E. S., Kim, K. T., Kim, J. K., Lee, J. M., \& Choi, J. Y., (2013). Assessment of heavy metal contamination and its ecological risk in the surface sediments along the coast of Korea. Journal of Coastal Research, 65, 105-110. https://doi.org/10.2112/SI65-019.1 


\section{Qadir et al., / Basrah J. Agric. Sci., 35(1): 21-34, 2022}

Rigueiro-Rodríguez, A., Mosquera-Losada, M. R., \& Gatica-Trabanini, E., (2000). Pasture production and tree growth in a young pine plantation fertilized with inorganic fertilizers and milk sewage in northwestern Spain. Agroforestry Systems, 48, 245-256. https://doi.org/10.1023/A:1006233204645

Sabr, H., \& Yunis, A. (2017). Impact of sewage water on growth of Eucalyptus camadulensis Dehnh. and Melia azedarach L. Seedlings. Polytechnic Journal, 7, 1-10.

Salman, S. A., Zeid, S. A., Seleem, E. M. M., \& AbdelHafiz, M. A., (2019). Soil characterization and heavy metal pollution assessment in Orabi farms, El Obour, Egypt. Bulletin of the National Research Centre, 43, 1-13. https://doi.org/10.1186/s42269-019-0082-1

Shi, G., \& Cai, Q., (2009). Cadmium tolerance and accumulation in eight potential energy crops. Biotechnology Advances, 27, 555-561. https://doi.org/10.1016/j.biotechadv.2009.04.006

Singh, G., \& Bhati, M., (2005). Growth of Dalbergia sissoo in desert regions of western India using municipal effluent and the subsequent changes in soil and plant chemistry. Bioresource Technology, 96, 1019-1028. https://doi.org/10.1016/j.biortech.2004.09.011

Smith, S. D., Wellington, A. B., Nachlinger, J. L., \& Fox, C. A., (1991). Functional responses of riparian vegetation to stream flow diversion in the eastern Sierra Nevada. Ecological Applications, 1, 89-97. https://doi.org/10.2307/1941850
Tomlinson, D. L., Wilson, J. G., Harris, C. R., \& Jeffrey, D. W., (1980). Problems in the assessment of heavymetal levels in estuaries and the formation of a pollution index. Helgolander Meeresunters, 33, 566575. https://doi.org/10.1007/BF02414780

Toze, S., (2006). Reuse of effluent water-benefits and risks. Agricultural Water Management, 80, 147-159. https://doi.org/10.1016/j.agwat.2005.07.010.

Turner, A. P., \& Dickinson, N. M., (1993). Survival of Acer pseudoplatanus L. (sycamore) seedlings on metalliferous soils. New Phytologist, 123, 509-521. https://doi.org/10.1111/j.1469-8137.1993.tb03763.x

Vollenweider, P., Menard, T., \& Günthardt-Goerg, M. S., (2011). Compartmentation of metals in foliage of Populus tremula grown on soils with mixed contamination. I. From the tree crown to leaf cell level. Environmental Pollution, 159, 324-336. https://doi.org/10.1016/j.envpol.2010.07.013

Wiszniewska, A., Hanus-Fajerska, E., Muszyńska, E., \& Smoleń, S., (2017). Comparative assessment of response to cadmium in heavy metal-tolerant shrubs cultured in vitro. Water, Air \& Soil Pollution, 228, 304. https://doi.org/10.1007/s11270-017-3488-0

Zhou, W., \& Qiu, B., (2005). Effects of cadmium hyperaccumulation on physiological characteristics of Sedum alfredii Hance (Crassulaceae). Journal of Plant Science, 169, 737-745. https://doi.org/10.1016/j.plantsci.2005.05.030 


\section{Qadir et al., / Basrah J. Agric. Sci., 35(1): 21-34, 2022}

\section{أداء نمو القوغ الاسود .Populus nigra L تحت ظروف الجفاف و الري بمياه المجاري \\ سروه انور قادر ' وهه لمهت ابوبكر صابر " وعبدالقادر مشير يونس"

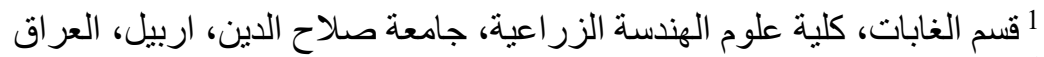

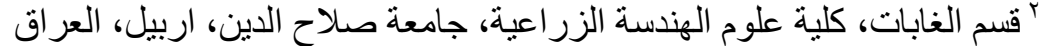

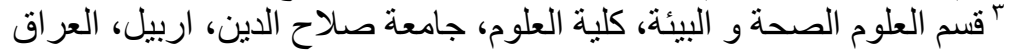

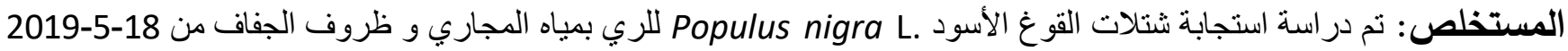

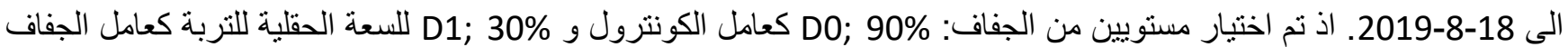

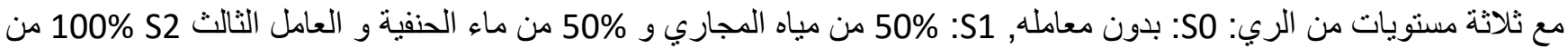

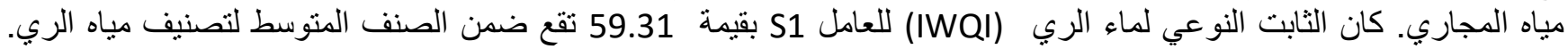

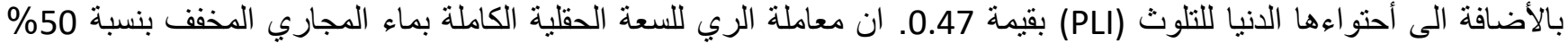
(S1D0)

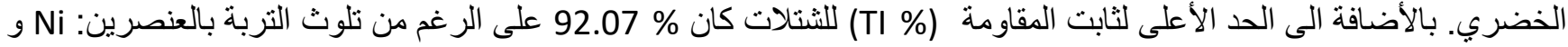

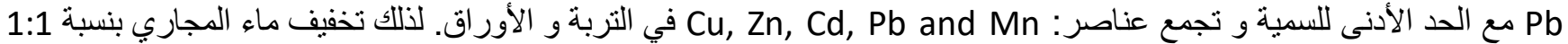

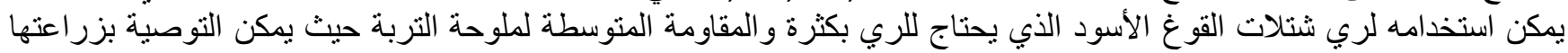
لصيانة الغابات و تشجير المدن.

الكلمات المفتاحية: المعادن الثقيلة، الكتلة الحيوية الثتلة، مياه الصرف الصحي، تراكم المعادن،.Populus nigra L. 